\title{
BILINGUALISM AND INTERFERENCE AS TENDENCIES OF LINGUISTIC DEVELOPMENT OF MODERN EDUCATIONAL SPACE IN CONDITIONS OF EDUCATIONAL INTERNATIONALIZATION
}

\author{
Томас Бауер ${ }^{1}$, О. М. Царик ${ }^{2}$ Н. В. Рибіна ${ }^{2}$ \\ ${ }^{1}$ Віденська вища педагогічна школа, Відень, Австрія \\ ${ }^{2}$ Тернопільський національний економічний університет
БІЛІНГВІЗМ ТА ІНТЕРФЕРЕНЦІЯ ЯК ТЕНДЕНЦІЇ ЛІНГВІСТИЧНОГО РОЗВИТКУ СУЧАСНОГО НАВЧАЛЬНОГО ПРОСТОРУ В УМОВАХ ОСВІТНЬОЇ ІНТЕРНАЦІОНАЛІЗАЦЇ̈

\begin{abstract}
The article is devoted to the study of bilingualism and interference problems in the development of modern society. The paper elaborates a theoretical background for the analysis of those two phenomena. As a result, the research has found that in the process of intercultural/interlingual communication there is an inevitable clash of two languages, the result of which is a new cognitive emotional language cultural space, which is a manifestation of interference. The paper has also proposed solutions to the problem of interfered speech. It has been given the available programs for foreign languages improvement as well as recommendations for future studying of these very problems.
\end{abstract}

Key words: bilingualism; interference; language cultural space; inter-language communication; internationalization.

Анотація. Стаття розкриває особливості вивчення проблем білінгвізму та інтерференції в контексті сучасного суспільства. Робота присвячена власне теоретичному підґрунтю цієї проблеми та реальній ситуації в сучасному освітньому просторі. У результаті здійсненого дослідження встановлено, що в процесі міжкультурного/міжмовного спілкування відбувається неминуче зіткнення двох мов, запропоновано шляхи вирішення проблеми вдосконалення мовленнєвих навичок. Авторами було надано доступні програми для вдосконалення рівня володіння іноземними мовами, а також рекомендації щодо подальшого вивчення цих самих питань.

Ключові слова: білінгвізм; інтерференція; мовний культурний простір; міжмовна комунікація; інтернаціоналізація.

Introduction. The XXI century is a new stage in the development of modern society. Most of the political, economic and socio-cultural changes of recent years are inextricably linked to the aspirations of countries in general and Ukraine, in particular, to an open society and integration into a single European cultural and educational space [6]. Rapidly developing international relations lead to the close interaction of different cultures and civilizations. There are few places in the world where residents face only one mother tongue in their lifetime. Television, media, internet are getting

(c) Thomas Bauer, O. M. Tsaryk, N. V. Rybina everywhere, so different foreign languages become the ways of communication. Foreign languages are included in many countries in the educational minimum of school and university programs, and quite often the language of education differs from the mother tongue. The above processes significantly affect the language situation in general. The internationalization and consequently development of an open information and communication space creates the prerequisites and conditions for the expansion of bilingualism as a leading tendency for the linguistic development of modern society. However, the disadvantage of this 
situation is the interference that involuntarily arises if you are fluent in two or more languages.

The relevance of our research is determined by the focus of current research in the field of linguistics on the study of linguistic conceptualization of knowledge, the combination of cognitive and communicative approaches to the analysis of linguistic and speech facts, in particular bilingualism and interference.

The aim - to establish the peculiarities of these phenomena by analyzing the main tendencies of linguistic development of modern society which is undergoing the process of globalization in general and educational internationalization in particular.

Theoretical framework. The study of such a plan is one of many currently implemented, focused on the identification of national specificities and linguistic differences in English and Ukrainian language, establishing patterns of functional changes that accompany the phenomenon, the interpretation of the causes of interference and the disclosure of mechanisms of interference cognitive linguistics. There are the issues of identifying the causes of linguistic interference in the context of bilingualism, clarifying its role and function in the social aspect (B. Azhniuk, Yu. Desheriyev, U. Labov, A. TabureKeller, J. Fishman, W. Lambert, S. Romaine, J. Walters), psychological aspect (E. Vereshchagin, O. Zalevskaya, I. Zimnaya, I. Usov, K. Cantone, F. Grosjean, R. Javier, J. Macnamara, K. Vaid), neurological aspect (N. Bekhtereva, O. Luria, T. Chernihivsk, R. Jacobson, L. Obler, M. Paradis, J. Schumann) and linguistic aspect (V. Alimov, O. Valigura, V. Karaban, O. Ohui, O. Petrenko, S. Semchinsky, O. Taranenko, O. Tkachenko, O. Cherednichenko, W. F. Mackey, R. C. Major, N. Poulisse) [2].

It is worth noting that, in turn, bilingualism as a modern socio-cultural phenomenon which develops under the influence of the following factors: enhancing the role of the socio-cultural component i.e. studying the culture of other countries and a deeper awareness of one's own culture, participating in a "dialogue of cultures"; creation of a unified educational space (general European educational space, international educational space) and, as a consequence, people's desire to achieve a common European level of command of foreign languages; development of academic mobility of students and teachers; the need for bilingual training as a means of vocational training, which enables future professionals to realize their potential and actively work in the world market, as well as a significant increase in inter-professional exchanges in the XXI century; development of world information space, rapid spread of such modern information and communication technologies as television and Internet, various mass media; use of new information and communication technologies, development of distance learning, on-line training, etc.

In this context, bilingualism, as a tendency of the linguistic development of modern society, enables a person to become aware of his place and his culture in the dialogue of cultures and civilizations in the process of cooperation and collaboration with other people. Currently, multicultural bilingual education through native and foreign language learning is an important part of modernizing the goals and content of national education systems in European countries (including Ukraine). Another factor that is important for the development of bilingualism is Ukraine's accession to the process of higher school internalization.

The internationalization of higher education is directly linked to the increased access of different segments of the population to different levels and levels of education, the individualization of the choice of ways and methods of obtaining knowledge [1]. UNESCO documents indicate that over the past 25 years, migration of academically minded youth has increased more than $300 \%$ internationally. The opportunities offered to students by academic mobility are an effective motivator for learning foreign languages. The European practice of organizing bilingual educational programs and courses that provide an international dimension in the content of higher education enables students to be prepared for international cooperation in various fields of activity of people in a foreign language world. Bilingual preparation is carried out within the framework of the following European Union programs [5, 7, 9]:

- Erasmus + (KA1, KA2, KA3) is the European Union programme that aims to promote cooperation between universities in Europe and worldwide as well as the mobility of students, graduates, lecturers and general university staff. Main points of the program are the recognition of academic achievements abroad on the basis of the European Credit Transfer system (ECTS) and the financial support of exchange students. The program is supervised in Germany by The German Academic Exchange Service (DAAD) and in Austria by National Agency Erasmus + Education, OeAD$\mathrm{GmbH}$;

- Erasmus Mundus, a program of cooperation and mobility in higher educational establishments and enabling students and young scientists from all over the 
world to receive postgraduate education at European universities;

- Tempus, a cooperation program in higher education that enables universities, colleges, agencies and companies in Sweden and other EU countries to interact. Projects include student exchanges, the development of new courses, and the dissemination of previously completed projects;

- A year abroad in France, Spain or Germany, enabling them to study French, Spanish or German in these countries;

- IAESTE program - an international internship for university students;

- DAAD (German Academic Exchange Service) - an organization of higher education institutions in Germany. As of 2015, DAAD brings together 232 German universities and 129 student organizations, mediates in the organization of foreign cultural policy, as well as German higher education and science policy. DAAD has 14 overseas offices and 50 information centers around the world and issues around 50,000 scholarships per year;

- OeAD is the Austrian agency for international mobility and cooperation in education, science and research. With a budget of more than 70 million euros and more than 250 employees in 2020, the OeAD promotes and connects people and institutions with future-oriented programmes in education, science, research and culture.

All in all, teaching staff and students are actively involved in the implementation of joint educational programs and are given the unique opportunity to study special subjects in a foreign language at partner universities. Studying abroad, learning the culture and traditions of another country allow them to take a different look at their own culture and customs, enhance their bilingual training and become a fullfledged subject in modern society. In addition, they convincingly prove the quality of education in their home university to international standards, participating in various representative international competitions and international scientific conferences (in foreign language).

Internationalization is widely launched in the higher education sector and has a positive connotation. Almost no European university can do without implementing this process.

Previous experience of integration of classic trips abroad and guest lecturers into everyday university life turned into the concepts and strategies for the further development of higher education institutions.
Bilingualism plays a crucial role in this process since international exchange or bilateral development is impossible without it.

Over the past three decades, such terms as internationalization of the university, curricula, and internationalization@home have been inextricably linked to mobility and in particular to the Erasmus program.

Teichler (2007) states, “... more than ever before, universities feel challenged to respond to the internationalization of their environment and to become more international in many [sic] respects. Internationality is no longer marginal for university life, it involves all its areas; casuistic activities are replaced by systematic strategies of internationalization. Students and scientists are becoming more mobile, universities are developing cross-border training courses, research cooperation is becoming global, English language is acquiring the status of a scientific lingua franca" [13].

"Internationalization is considered by the universities as a subject-matter task that runs through all areas of the university and therefore relates to many development strategies. Own internationality is proved by the involvement of international students and staff, or the integration into international networks, and is a characteristic feature of science in general, or a seal of quality for the particular institution” [10].

Greiner (2017) makes a differentiation, "We distinguish content, internationally oriented organizational forms of teaching and development, personal mobility, cooperation in the tertiary systems... internationalization is a subject-matter task" [11].

Many universities have already laid down the internationality in the status and discussed the interregional focus of the activities. It is also possible to find already defined regions for bilateral cooperation or strategic partnerships [10].

The common actions of internationalization for all European universities are participation in European programs and international partnerships and setting the growth of outgoing mobility as a priority objective. More than two-thirds of the universities consider internationalization at home through incoming mobility and extended courses in English as an important instrument for internationalization.

A study conducted by the European Parliament on the internationalization of universities (De Wit 2016) gives a clear view towards the concept of internationalization that Jane Knight attempted in the late 1990s: “...the intentional process of integrating an international, intercultural or global dimension into the purpose, 
functions, and delivery of higher education, to enhance the quality of education and research for all students and staff, and to make a meaningful contribution to society" [8].

Internationalization is an effective tool on the way to strengthening the quality of education and research, enabling students and staff of particular higher education institution to make a meaningful contribution to the society [8].

Besides, the ECHE (Erasmus Charter for Higher Education) has laid down the corresponding principles and standards for quality mobility [12].

Austrian universities, together with the Federal Ministry of Education, Science, and Research, are developing the Higher Education Mobility Strategy (HMS), “...to promote transnational physical mobility. This involves, among other things, the quantitative and, in particular, qualitative improvement of transnational physical mobility among students, young researchers and teaching staff in the higher education sector" [12].

In general, bilingualism is becoming a hallmark of culture, and the need to understand this phenomenon in the context of the development of cultural values is the most important task of the modern stage of development of civilization. However, interference (for the first time this term originated at the Prague Linguistic School, where it was defined as a process of deviation from the norms of communicating languages) as a process and result of the speech process, constitutes a violation of the carrier of bilingualism and multilingualism of the rules of the relation of the contact languages, which are manifested in his language in deviation from norms [4]. Interference is an integral part of the process

\section{List of literature}

1. Бирюкова Н. А. Формирование социальной мобильности личности в высшей школе / Н. А. Бирюкова, С. Л. Яковлева. - Йошкар-Ола : Изд-во Мар. гос. ун-та, 2008. - 188 с.

2. Валігура О. Р. Фонетична інтерференція в англійському мовленні українських білінгвів : монографія / О. Р. Валігура. - Тернопіль : Підручники і посібники, 2008. - 288 c.

3. Ковалева С. С. Билингвизм как социально-коммуникативный процесс : автореф. дисс. на соискание ученой степени канд. социол. наук / С. С. Ковалева. - М., 2006. - 25 с.

4. Малишева А. В. Проблема визначення терміну «мовна інтерференція» [Електронний ресурс] / А. В. Малишева. - Режим доступу : http://intkonf.org/ malisheva-av-problema-viznachennya-terminu-movnainterferentsiya/. of the slow, gradual penetration of a language element into the receptive language system [4]. Clearly, this is a negative sign of bilingualism that needs to be addressed through persistent learning and refinement of language skills. Thus, the need to study the complex problems associated with the formation and functioning of bilingualism has increased significantly in the face of a new wave of global integration. As a social phenomenon, bilingualism is gaining importance and becoming an important attribute of the information society. Bilingual education is now becoming an integral part of education. Knowledge of foreign languages allows each person to realize their accumulated potential regardless of place and time using all possible conditions, methods and methods of learning.

Conclusions and Prospects for Research. In general, learning a second language is the key to a successful career as a qualified specialist in demand in the labor market, able to work effectively at a professional level at a world standard level. Perspective directions of further linguistic search for ways to solve the problem under consideration include: finding out the peculiarities of forming linguistic switches in bilingual speech; revealing the impact of the linguistic picture of the world on the bilingual accent of the bilingual; study of the features of meaning encoding processes in interfering bilingual speech; establishment of specific perception of standard bilingual speech and interference with native speakers. Given the growing role of English as a means of intercultural communication, the study of interference with ethnospecific and linguocultural aspects is also promising.

5. Рибіна Н. Білінгвізм та інтерференція як тенденції мовного розвитку сучасного суспільства: проблеми та способи їх вирішення / Н. Рибіна // Наукові записки Національного університету «Острозька академія». Серія «Філологічна». - 2015. - Вип. 59. - С. 176-178.

6. Сафонова В. В. Билингвальные образовательные программы как инструмент обновления содержания языкового школьного образования [Электронный ресурс] / В. В. Сафонова. - Режим доступа : http: www. Fismozaika.ru/document/safonova.pdf.

7. Филимонова М. С. Билингвизм как тенденция языкового развития современного общества / М. С. Филимонова // Современные проблемы науки и образования. - 2012. - № 1. - Режим доступа : www.scienceeducation.ru/101-5558.

8. De Wit H. Challenges and opportunities for Internationalising Higher Education in Europe, in: Zotti S. (Hg.) 
International Lectures. 22 Beiträge zur Internationalisierung der Hochshulen. Innsbruck, Wien, Bozen: Studienverlag, 2016. - P. 36-40.

9. Directory of higher education institutions in the European Community // Second edition. - The Commission of the European Communities: Task Force for Human Resources, Education, Training and Youth, by Erasmus Bureau. Brussels, Luxembourg : Office for official publications of the European Communities, 2004. - 567 p.

10. Fiorioli E., Shovakar N. Measuring Internationalisation: Studierende zählen ist zu wenig, in: Zotti S. (Hg.): International Lectures. 22 Beiträge zur Internationalisierung

\section{References}

1. Biriukova, N.A., \& Yakovleva, S.L. (2008). Formirovanye sotsyalnoy mobilnosti lichnosti $v$ vysshey shkole [The formation of social mobility of a person in higher school]. JoshkarOla: Izd-vo Mar. gos. un-ta [in Russian].

2. Valihura, O.R. (2008). Fonetychna interferentsiia $v$ anhliiskomu movlenni ukrainskykh bilinhviv: Monohrafiia [Phonetic interference in the English language of Ukrainian bilinguals: Monograph]. Ternopil: Pidruchnyky i posibnyky [in Ukrainian].

3. Kovaleva, S.S. (2006). Bilingvizm kak sotsyalnokommunykativnyy protsess [Bilingualism as a sociocommunicative process]. Candidate's Extended abstract. Moscow [in Russian].

4. Malysheva, A.V. Problema vyznachennia terminu "movna interferentsiia" [The problem of defining the term "language interference]. Retrieved from: http://intkonf. org/malisheva-av-problema-viznachennya-terminu-movnainterferentsiya/ [in Ukrainian].

5. Rybina, N.V. (2015). Bilinhvizm ta interferentsiiayak tendentsii movnoho rozvytku suchasnoho suspilstva: problemy ta sposoby yikh vyrishennia [Bilingualism and interference as tendencies of linguistic development of modern society: problems and ways of their solution]. Naukovi zapysky Nacionalnoho universytetu "Ostrozka akademiia”. Seriia: Filolohichna - Scientific Notes of the National University "Ostroh Academy”. Series: Philological, 59, 176-178 [in Ukrainian].

6. Safonova, V.V. Bilingvalnyye obrazovatelnye programmy kak instrument obnovleniya soderzhaniya yazykovogo shkolnogo obrazovaniya [Bilingual educational programs as a tool for updating the content of language school education]. Retrieved from: http: www. Fismozaika.ru/document/safonova.pdf. der Hochschulen. - Innsbruck, Wien, Bozen : Studienverlag, 2016. - P. 26-31.

11. Greiner U. Internationalisierung der Lehrerbildung. Strategien an der Universität Salzburg / U. Greiner, P. Siwek-Macron // Journal für LehrerInnenbildung: Internationalisierung. - 2017. - No. 4. - P. 39-42.

12. Pichl E. Vorwort, in: Grenzen überschreiten. Facetten und Mehrwert von qualitätsvoller Auslandsmobilität in der Hochschulbildung / E. Pichl. - Wien : Gerin, 2017.

13. Teichler U. Internationalisierung der Hochschulen. Neue Herausforderungen und Strategien / U. Teichler. Frankfurt, New York : Campus, 2007.

7. Filimonova, M.S. (2012). Bilingvizm kak tendentsiya yazykovogo razvitiya sovremennogo obshchestva [Bilingualism as a trend in the linguistic development of modern society]. Sovremennyye problemy nauky i obrazovaniya Modern Problems of Science and Education, 1. Retrieved from: www.science-education.ru/101-5558.

8. De Wit, H. (2016). Challenges and opportunities for Internationalising Higher Education in Europe. Zotti $S$. (Hg.) International Lectures. 22 Beiträge zur Internationalisierung der Hochshulen. Innsbruck, Wien, Bozen: Studienverlag. P.36-40.

9. (2004). Directory of higher education institutions in the European Community // Second edition. The Commission of the European Communities: Task Force for Human Resources, Education, Training and Youth, by Erasmus Bureau. Brussels, Luxembourg: Office for official publications of the European Communities.

10. Fiorioli, E., \& Shovakar, N. (2016). Measuring Internationalisation: Studierende zählen ist zu wenig. Zotti $S$. (Hg.): International Lectures. 22 Beiträge zur Internationalisierung der Hochschulen. Innsbruck, Wien, Bozen: Studienverlag.

11. Greiner, U., \& Siwek-Macron, P. (2017). Internationalisierung der Lehrerbildung. Strategien an der Universität Salzburg. Journal für LehrerInnenbildung: Internationalisierung, 4, 39-42.

12. Pichl, E. (2017). Vorwort. Grenzen überschreiten. Facetten und Mehrwert von qualitätsvoller Auslandsmobilität in der Hochschulbildung. Wien: Gerin.

13. Teichler, U. (2007). Internationalisierung der Hochschulen. Neue Herausforderungen und Strategien. Frankfurt, New York: Campus. 